\title{
MEIOS DE COMUNICAÇÃO, VOTO E CONFLITO POLÍTICO NO BRASIL
}

\section{Flávia Biroli}

\section{Luis Felipe Miguel}

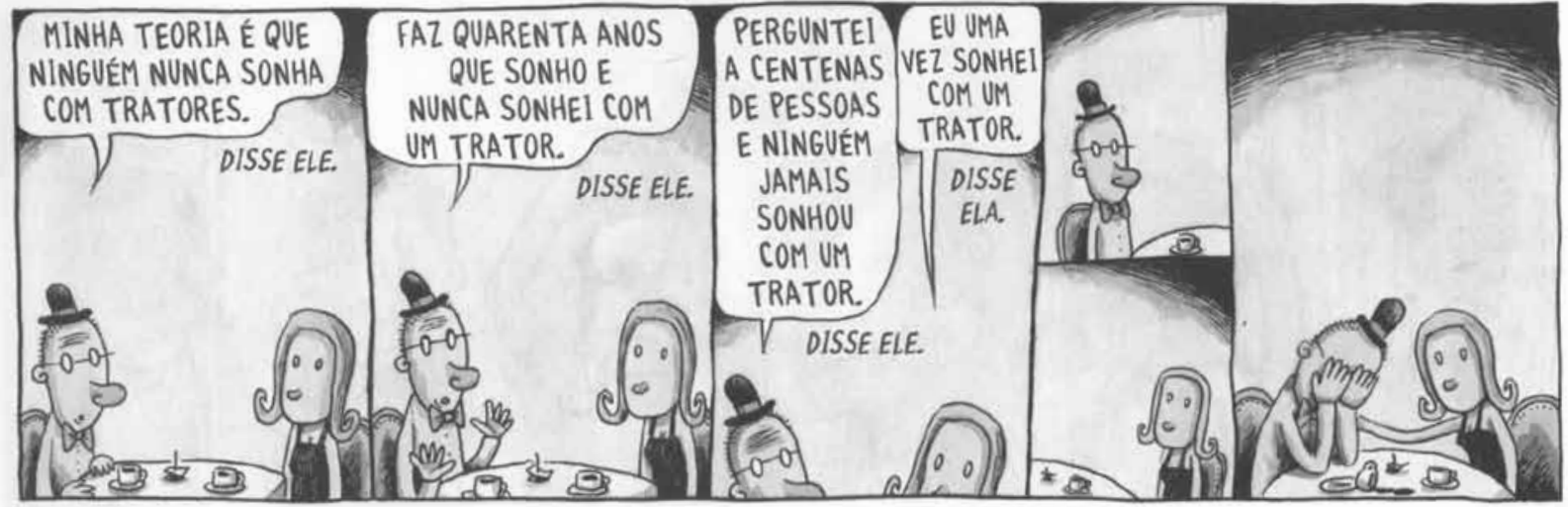

Liniers

Os estudos brasileiros sobre as relações entre a mídia e a política foram inaugurados pela eleição presidencial de 1989. Se antes havia uma ou outra pesquisa, em geral com a política aparecendo como aspecto secundário de uma "sociologia da comunicação" mais ampla, desde então começa a se constituir um campo interdisciplinar, que se afirma sobretudo nos períodos eleitorais. Embora a normalização democrática após 1985 , por um lado, e o Artigo recebido em 15/05/2011 Aprovado em 17/09/2012 desenvolvimento acelerado do ambiente acadêmico brasileiro, por outro, tenham contribuído para a eclosão desse ramo do conhecimento, é inegável o impacto que a vitória de Fernando Collor teve para seu surgimento - e também para sua evolução posterior (Rubim e Azevedo, 1998).

Collor foi um caso de manual, uma demonstração quase caricata da midiatização da política e do poder dos meios para moldar uma disputa eleitoral. Político sem expressão, tornou-se, em 1986, governador de um estado desimportante no cenário 
nacional, no bojo do Plano Cruzado - o PMDB, partido ao qual aderira meses antes, fez 22 dos 23 governadores nas eleiçóes daquele ano, graças ao grande apoio popular ao plano de estabilização econômica. Para viabilizar sua candidatura a presidente, Collor logo se transferiu para um micropartido, o Partido da Juventude, que ele rebatizaria como Partido da Reconstrução Nacional. O PMDB possuía muitos caciques mais poderosos do que ele e, além disso, encontrava-se enfraquecido com a débâcle do Cruzado, dias após as eleições.

Como foi possível que um político de segundo time, governador de um estado periférico, filiado a um partido sem qualquer estrutura coligado a outros dois igualmente desimportantes, tenha chegado à presidência da República? Muitos fatores ajudam a explicar o fenômeno, como o desespero dos grupos poderosos para, em face do desgaste das elites políticas tradicionais, encontrar o "anti-Brizula", isto é, o candidato capaz de derrotar a ameaça esquerdista, representada quer pelo ex-exilado Brizola, quer pelo ex-sindicalista Lula. Ou o fato de se tratar de uma eleição solteira, em que o único cargo em disputa era o de presidente, o que reduz significativamente o peso das máquinas partidárias e amplia as chances dos outsiders.

Mas ainda assim os meios de comunicação desempenharam um papel chave. Collor fez uma ofensiva midiática tão logo assumiu o governo de Alagoas, incluindo tanto ações de marketing pessoal quanto contatos que garantiram a simpatia dos controladores dos principais veículos. Criou a persona do "caçador de marajás", que foi difundida por televisões, jornais e revistas. Só a Veja deu uma capa ao tema dos "marajás" em agosto de 1987 e outra ao próprio Collor em março de 1988, marcas inéditas (e nunca depois igualadas) para um governador nordestino em começo de mandato, sem falar de mais três em 1989, durante a pré-campanha e a campanha para a presidência. Além disso, Collor colonizou o horário gratuito de propaganda partidária no rádio e na TV de três pequenas legendas, para se fazer conhecido do eleitorado.

Enfim, Collor não teria sido eleito sem o apoio das máquinas partidárias locais e dos grandes financiadores de campanha, mas foi a visibilidade inicialmente obtida na mídia que o tornou atraente para estes. Mais tarde, a mesma Veja capi- taneou a onda de denúncias que culminariam em seu impeachment, em 1992. Ou seja, a trajetória de Collor parecia comprovar que "a imprensa faz e desfaz um presidente" (Lattman-Weltman, Carneiro e Ramos, 1994).

As eleições presidenciais seguintes introduziram um pouco mais de complexidade, mas ainda assim permaneceram dentro do script. Em 1994, a promoção do Plano Real e a da candidatura de Fernando Henrique Cardoso andavam juntas - e as inconfidências do ministro da Fazenda, afirmando, sem saber que estava sendo transmitido, que a mistura entre campanha eleitoral e plano econômico havia sido "um achado" para a Rede Globo, só confirmaram a centralidade da mídia na indução da decisão do eleitorado. Em 1998, o relativo silêncio da mídia sobre a campanha correspondia à estratégia para a reeleição de seu candidato preferido, novamente Fernando Henrique. Mesmo em 2002, a vitória de Lula foi combinada com sua capitulação ao programa macroeconômico que antes combatia - e os meios desempenharam um papel crucial na imposição deste "consenso" (ver, entre muitos outros, Porto, 1995; Miguel, 1999, 2003, 2004; Aldé, 2004; Rubim, 2004).

Mas em 2006 os estudiosos de mídia e política se viram jogados num doloroso universo paralelo, em que os eleitores votavam num candidato que não era o apoiado pelos grandes conglomerados de comunicação. Desde a publicação da entrevista do deputado Roberto Jefferson ao jornal Folha de $S$. Paulo, em 6 de junho de 2005, até o primeiro turno das eleições presidenciais, foram dezesseis meses ininterruptos de cobertura negativa do governo Lula, focada no escândalo do "mensalão" e em seus desdobramentos. No entanto, Lula obteve $48,6 \%$ dos votos válidos no primeiro turno, $60,8 \%$ no segundo, reelegendo-se à presidência da República. Quatro anos depois, a história se repetiria com Dilma Rousseff, que, com 46,9\% dos votos válidos no primeiro turno e $56,1 \%$ no segundo, foi eleita presidente a despeito do apoio pouco disfarçado dos principais veículos de comunicação a seu adversário, José Serra.

Estes resultados trouxeram novas questôes às pesquisas na área de mídia e política, impondo a reflexão sobre uma série de problemas que estão 
na base das análises presentes em muitas delas. $\mathrm{O}$ descompasso entre as hipóteses de pesquisa e o modo como as disputas se definiram nas eleições recentes pode definir o caráter das indagações nesse campo: por que há uma cisão entre a mídia e as preferências do eleitorado - ou, se preferirmos utilizar um conceito mais desafiador, entre a mídia e a opinião pública.

Mas esta é uma falsa questão, como procuraremos mostrar aqui. Ela é útil apenas por revelar os pressupostos simplificadores que subjazem a grande parte da pesquisa sobre mídia e política ou, de forma mais precisa, sobre a influência dos meios de comunicação nos processos eleitorais. As explicações para o peso da mídia na formação das preferências (ou conformação da opinião pública) são muitas vezes simplificadoras porque:

- pressupõem um eleitorado menos heterogêneo do que ele de fato é e processos mais unidimensionais de definição das preferências do que de fato são;

- pressupõem "a mídia” como redutível aos principais conglomerados comerciais e tratável como bloco monolítico, e não uma rede complexa em que produção e circulação das informações não se reduzem a uma dinâmica centralizada e controlada;

- pressupõem as relações entre mídia e eleitorado a partir de (1) e (2).

Isso leva a equívocos e simplificações tanto na explicação de por que a mídia tem peso na definição das preferências (ou conformação da opinião pública) como na explicação de por que, em outros casos, ela não é determinante.

$\mathrm{Na}$ primeira seção do artigo, discutimos e criticamos estes três pressupostos. $\mathrm{Na}$ segunda, procuramos avançar alguns passos na direção de um entendimento mais sofisticado dos fluxos de comunicação e da formação das preferências políticas nas sociedades contemporâneas (e no Brasil de hoje em particular). Aqui, a diversidade do tecido social, de um lado, e, de outro, a complexidade dos circuitos comunicativos, que não se limitam à "grande imprensa", precisam entrar em cena. Por fim, uma breve conclusão procura contribuir para a compreensão do poder da mídia na conformação do ambiente político, dando destaque às disputas e antagonismos que constituem os processos de produção dos discursos e de definição das preferências políticas.

\section{A seringa oculta}

Expressões como "o eleitorado" ou "a opinião pública" tendem a apresentar como unidade aquilo que pode, no máximo, ser entendido como o resultado de pressões conflitantes. Usadas por economia de linguagem, acabam por contribuir para a sedimentação de esquemas mentais simplificadores. Em particular, contribuem para que se julgue que as respostas às influências e pressões do ambiente político são uniformes, quando, ao contrário, é crucial entendê-las como profundamente diferenciadas.

A análise do comportamento eleitoral depende do entendimento que se tem de como as preferências dos votantes são produzidas. Se não é possível nem desejável que cada estudo da relação entre mídia e eleições enfrente problemas de base, como a caracterização dos processos de formação das preferências, é sempre necessário estar consciente dos pressupostos que são mobilizados e dão forma às análises.

Um primeiro pressuposto que é necessário discutir é o peso conferido à posição social dos eleitores - ou, dito de outra forma, o impacto das clivagens sociais internas ao eleitorado nos processos de definição das preferências e do voto. Trata-se do entendimento de quanto e como classe social, nível educacional, poder de compra, lugar de moradia, sexo, raça, geração, relação com religiões organizadas e outras clivagens contam na definição do voto. Se essas variáveis pesam, pode-se presumir que as mesmas informações despertam graus de atenção e ganham sentidos diferentes para indivíduos diversamente situados. A matéria de que são produzidas as identidades sociais dos indivíduos é, nesse caso, determinante para a maneira como compreendem o que está em jogo nas disputas políticas e consideram as alternativas e informações que lhes são apresentadas.

Até certo ponto, estamos repisando o entendimento de que a recepção é social e ativa. Já Walter 
Lippmann ([1922] 1966) ressaltava as predisposições e os preconceitos que, resultantes do ambiente social em que os indivíduos estão imersos, definiriam a visão subjetiva das informaçōes disponíveis. John Thompson ([1990] 2002), influente entre os estudiosos brasileiros no campo da comunicação e política, enfoca o impacto dos meios técnicos de comunicação lembrando, em diversos momentos de sua análise, que os discursos que a mídia faz circular são concretamente recebidos, apropriados e reelaborados em contextos particulares.

Não é, portanto, novidade dizer que os indivíduos estão diferentemente atentos e são diferentemente permeáveis às narrativas que compõem o ambiente informacional em que estão inseridos. Mas há uma distância entre a "crença" no caráter ativo da recepção e a incorporação desse fato complexo aos modelos analíticos. Ao analisar o discurso da mídia nos períodos eleitorais, por exemplo, consideramos que ele tem peso na orientação das disputas e, sobretudo, na definição do voto. E é comum que ele seja entendido a partir de uma recepção-padrão ao que, da perspectiva do analista (ou do jornalista), é relevante. O comportamento eleitoral é, então, entendido como uma resposta ao "ambiente informacional” em que o próprio analista ou jornalista está situado. Nesse caso, premissas similares organizam a produção acadêmica e a produção jornalística, ainda que com graus diferentes de sofisticação. Isso permite que exista uma continuidade entre elas, uma alimentação recíproca do universo mental em que os fatos ganham sentido. Ao dar sentido ao voto, acadêmicos e jornalistas o fazem a partir da posição de quem detém um leque maior de informações em relação às informações de que dispõe o eleitor -, mas sobretudo a partir de valores e framings que não necessariamente coincidem com aqueles que foram, de fato, mobilizados pelos eleitores na definição das suas preferências e opiniōes.

Assim, imputa-se ao voto a expressão de uma opinião que, no entanto, é apenas uma projeção do discurso acadêmico ou jornalístico. Por exemplo, o voto em Lula, expressão do "lulismo", demonstraria despreocupação com a moralidade na gestão do patrimônio público ou vulnerabilidade do eleitor à manipulação por meio de práticas assistencialistas. Trata-se de uma manifestação daquilo que Bour- dieu (1997, p. 64) chama de transfusão da razão raciocinante para a razão razoável. O sentido do voto é o sentido atribuído ao voto a partir da posição e dos interesses de determinados segmentos do eleitorado, no caso os setores bem posicionados no mercado de produção e circulação dos discursos.

No Brasil, metodologias que permitiram analisar o "viés" dos meios de comunicação em contextos eleitorais tiveram um grande impacto na área de comunicação e política. As análises centradas na "valência" do material jornalístico, por exemplo, exigem dois pressupostos para que seus resultados tenham relevância: (1) que a atribuição do caráter "positivo", "negativo" ou "neutro" a uma reportagem pelo pesquisador seria compartilhada pelos jornalistas, pelos agentes políticos envolvidos e por todos os segmentos do público; e (2) que seja possível estimar a priori o impacto do noticiário positivo ou negativo no público, mais uma vez visto como indistinto. Estes pressupostos comprometem mais a utilidade do uso da valência do que os problemas de operacionalização vinculados à dificuldade de mensurar seja o peso das diferentes matérias, seja seu grau de "positividade" ou "negatividade". ${ }^{1}$

As análises podem ressaltar, por exemplo, que eleitores de diferentes estratos socioeconômicos definem seu voto a partir de experiências que são diversas, ao mesmo tempo em que naturalizam julgamentos sobre o sentido - e o teor moral - da relação entre voto, posição social e interesses dos eleitores. $\mathrm{O}$ fato de que o eleitor receba benefícios de um programa social do governo federal, por exemplo, tem sido uma variável considerada nas análises sobre as eleições de 2006 e 2010 . Permite associar renda, relação com o governo federal, e mesmo relativizar, entre os beneficiários, o impacto da cobertura jornalística negativa para o governo ou candidatos governistas. Mas a razão e $o$ sentido desses votos são explicados a partir de categorias que podem ser estranhas àquelas que estão na base da decisão daquele segmento do eleitorado e/ou que estigmatizam o eleitor, colocando em questão suas razões para aderir a um ou a outro candidato (Marques, Leite, Mendes e Ferreira, 2009; Zucco, 2008).

Ainda que as análises não promovam a estigmatização do comportamento político, movem-se 
num universo simbólico comum ao da cobertura jornalística. Nesse campo, a estigmatização do comportamento político dos segmentos mais pobres da população tem sido recorrente. Tem se dado em momentos históricos distintos, como os anos que antecederam o golpe de 1964 (Biroli, 2005), permanecendo em visões elitistas da democracia que se acomodam a análises produzidas em vários campos, entre eles a mídia e a academia. A cobertura sobre o Programa Bolsa Família no período eleitoral de 2006 é um exemplo. Nela, é frequente a associação entre assistencialismo e manipulação e a pressuposição de que os eleitores pobres são vulneráveis à manipulação - que, assim definida, permite que o comportamento presumido de um dos agentes (o eleitor) reitere o comportamento presumido de outro (o governo ou o PT). Além disso, os sentidos atribuídos aos interesses dos eleitores diferem se são pobres ou ricos: no primeiro caso, o voto resultaria de manipulação e desconsideraria questões éticas, no segundo, o voto resultaria de uma visão objetiva dos próprios interesses. Esse entendimento esteve presente no noticiário dos jornais diários de circulação nacional durante o período eleitoral de 2006, quando o Bolsa Família apareceu como a principal motivação, ilegítima, para o votos dos eleitores pobres em Lula.

Nesse caso, os valores mobilizados pela análise seriam universais, diluindo suas conexões não apenas com perspectivas sociais e interesses específicos, mas com a própria disputa eleitoral. É porque esses valores são apresentados como universais (o zelo pelos recursos públicos, a compreensão de que o Estado está acima dos interesses partidários, o entendimento de que interesses privados não devem moldar a atuação dos homens públicos etc.) que diferenças e antagonismos são apresentados como desvios. A distinção entre comportamento autointeressado e comportamento republicano, por exemplo, ganha matizes diferentes se os interesses são considerados legítimos ou não - a defesa da propriedade, de modo geral, aparece desconectada da noção de autointeresse.

$\mathrm{Na}$ definição do sentido do voto, boa parte das análises desconsidera que (1) os eleitores podem dispor de informaçōes diferentes daquelas de que dispõem os estudiosos; (2) os eleitores podem mo- bilizar as informações - coincidentes ou não com aquelas que se espera que pesem na definição do voto - em narrativas que não reproduzem os framings hegemônicos na grande mídia. Mas, principalmente, as análises deixam de lado a importância que pode ganhar, em disputas específicas, (3) o conflito entre informações e representações antagônicas. Esse terceiro ponto adianta uma questão que será discutida em seguida, a de que a existência de um sistema de mídia em que há grande concentração na propriedade e alto grau de homogeneidade nas práticas jornalísticas de produção das informações é confundida com monopólio estrito sobre a circulação das informaçōes, controle ou, ao menos, prevalência da "grande imprensa" entre as instituições e espaços em que são produzidos os discursos que teriam impacto para a decisão dos eleitores.

Queremos ressaltar que a interpelação que está no centro da dinâmica informacional não pode ser explicada a partir das informações disponibilizadas pelos meios de comunicação. Isso não significa que essas informações não devam ser caracterizadas e analisadas para entendermos as relações entre a mídia e as disputas eleitorais em um dado momento. $\mathrm{O}$ que simplifica a dinâmica de produção das informações - e compromete as conclusões dos pesquisadores - é tomar as categorias que estão na base do discurso da própria mídia como fundamento para interpretar o comportamento eleitoral. Quando isso se dá, o foco recai sobre o maior ou menor ajuste àquelas categorias e não sobre a dinâmica complexa de produção das decisões, em que há uma sobreposição conflituosa de referências, informações e orientações.

O voto em Collor, em 1989, tem sido visto como expressão da influência da mídia sobre o eleitorado. A maior parte das análises procura explicar a opção de setores da elite econômica, incluídos os proprietários de mídia, à candidatura de Collor, e pouco se diz sobre as razões do eleitorado - que teriam sido produzidas por uma combinação de imaturidade política, após 29 anos sem votar para presidente, e orientação hipermidiática da disputa. $\mathrm{O}$ voto não aparece como desvio, ainda que a conduta do candidato eleito o tenha sido. O comportamento dos eleitores não foi explicado do ponto de vista ético, assim como a adesão da imprensa não 
foi reconhecida, muito menos apresentada como uma falta ética. Já em 2006 e em 2010, o sentido do voto em Lula e Dilma se definiu em um contexto no qual a grande imprensa havia se colocado na ofensiva diante da corrupção no governo. $\mathrm{O}$ voto em Lula expressaria, assim, a ausência de preocupação da maior parte do eleitorado com os aspectos éticos da política. Nesse caso, o voto teria sido um desvio em pelo menos dois sentidos: não sofreu o impacto da cobertura da grande imprensa, de um lado, e, de outro, revelou uma conduta moral desviante, sobretudo do eleitorado pobre, em especial das regiōes Norte e Nordeste do país (Biroli e Mantovani, 2010).

As preferências e opiniōes individuais são, no entanto, efeito de relaçōes sociais complexas, em que os recursos para a definição da opinião e sua expressão variam segundo a posição social objetiva dos indivíduos e excedem a agenda e os enquadramentos midiáticos. Mas o comportamento dos eleitores, por outro lado, não se define à parte dos valores políticos hegemônicos. Os pressupostos presentes nos discursos hegemônicos sobre quais informaçôes deveriam ser mobilizadas e quais valores deveriam estar na base das motivações dos eleitores não constituem um universo simbólico paralelo àquele em que as decisões são tomadas. Os meios de comunicação podem não determinar o voto, mas atuam dando ênfase a determinadas compreensões da política, definindo fronteiras entre comportamento adequado e inadequado, lapidando consensos. Além disso, os discursos que a "grande imprensa” coloca em circulação podem ser um índice de quais são as compreensões da política que se tornaram hegemônicas no campo mais amplo e heterogêneo da produção ideológica, e não apenas no campo midiático.

Discutimos, até aqui, o primeiro pressuposto, que consiste nos entendimentos sobre a produção das preferências dos votantes que estão na base das análises sobre a mídia e a política. O segundo pressuposto aponta para questões relacionadas à produção e circulação dos discursos. Consiste no entendimento de quais são os dispositivos de produção ideológica que pesam na definição das preferências e do voto e qual é seu impacto sobre o público. Em outras palavras, o problema aqui é a compreensão, nem sempre explicitada, de como se organiza o campo de produção ideológica e quais seus efeitos na produção da opinião pública. Qual é o peso da mídia - e, em particular, da grande mídia comercial - em relação a outras instituições ou espaços a partir dos quais se definem fluxos, menos ou mais controlados e centralizados, de informações, como governos, igrejas ou organizações não governamentais?

A maior parte das pesquisas sobre mídia e eleições no Brasil concentra-se em dois problemas: a definição da agenda da "grande imprensa" (os temas e enquadramentos predominantes nos jornais impressos e telejornais de maior público, durante o período eleitoral) e a adesão dessa mesma mídia a uma ou outra candidatura (a visibilidade dada a temas e enquadramentos e a cobertura positiva ou negativa dos candidatos, partidos políticos e governo). O "ambiente político" acaba sendo definido a partir do comportamento da própria mídia ou, mais especificamente, de segmentos da mídia. Em geral, ficam de fora pelo menos dois aspectos necessários à caracterização do tipo e do grau de influência da mídia: o noticiário cotidiano e seu impacto na definição dos valores políticos dos eleitores, ultrapassando, portanto, a cobertura eleitoral; e os "valores de fundo" que organizam o próprio noticiário, isto é, os discursos valorativos de caráter mais permanente que são o pano de fundo que dá sentido às informações e justifica sua saliência em relação a outras. ${ }^{2}$

Além dessas, interessa-nos uma outra ausência nessas análises, a do contraditório que é parte do fluxo de informações. Nesse aspecto, é comum que se desconsidere que: (1) internamente à grande imprensa, há "camadas" de discursos cujos sentidos não convergem plenamente, apresentando contradiçōes e fissuras; (2) internamente ao campo da mídia, há segmentos diferentes que contribuem para reforçar discursos que podem ser convergentes, apresentar divergências pontuais ou ser de fato antagônicos; e (3) externamente ao campo da mídia, há espaços e instituições que produzem discursos que concorrem com aqueles que os meios de comunicação fazem circular. Nos três casos, além da consideração de que o fluxo comunicativo contém contradiçôes, a análise mais detida desses aspectos, ou sua consideração na elaboração dos problemas 
de pesquisa, levaria a uma maior atenção ao problema discutido no primeiro pressuposto, o da atenção diferenciada de segmentos distintos do público às informaçōes disponíveis.

Essas instituições (incluídos diferentes tipos de mídia, mas também aquelas que não são propriamente pertencentes ao campo da mídia) colocam em circulação temas que podem definir a agenda das disputas e atuam na delimitação do campo do politicamente pensável. Podemos entendê-las como dispositivos de verdade, no sentido de que participam (convergindo ou divergindo) da definição do "conjunto das regras segundo as quais se distingue o verdadeiro do falso e se atribui ao verdadeiro efeitos específicos de poder" (Foucault, [1979] 1995, p. 13). Assim, mais do que a adesão a posiçỗes e candidatos, é preciso compreender como se dá a construção e o reforço às próprias categorias e valores que estão na base dos julgamentos (Biroli e Miguel, 2012). E ela não se origina ou tem efeitos a partir, apenas, dos discursos hegemônicos na grande imprensa.

A compreensão do modo como esses dispositivos atuam é deformada quando se entende que um deles atua sozinho ou é necessariamente determinante das informações (re)produzidas pelos demais. Em boa parte das pesquisas sobre mídia e política, um sistema complexo de meios de comunicação é representado pelas posições de um punhado de grandes veículos. Em suma, as pesquisas podem concentrar-se no Jornal Nacional ou em alguns poucos jornais diários de circulação nacional e dos seus posicionamentos desdobrar análises da "mídia". Se há duas décadas, quando essa área de estudos começou a ganhar dimensão no Brasil, isso já era uma simplificação, hoje o peso destes veículos mudou, o campo da mídia no Brasil se tornou mais complexo, a comunicação governamental atua com impacto direto e indireto sobre a própria mídia comercial, os espaços e redes de produção e circulação de informação se ampliaram.

Mas é o terceiro pressuposto anunciado na introdução que nos permite tratar da relação que as análises pressupõem que a mídia deve ter com a opinião do público (não no sentido de observância a uma norma ética, mas de adequação aos modelos e pressupostos que estão em sua base). É aqui que vemos que as velhas teorias hipodérmicas, apesar de todas as críticas já recebidas e mobilizadas pelos próprios estudiosos, continuam organizando muitos esquemas mentais. Vem daí o espanto com o fato de que o eleitorado escolha um candidato que recebe a desaprovação expressa da grande mídia.

As críticas à teoria hipodérmica, com o foco nos fluxos horizontais de informação e no peso do ambiente social, não impedem que a relação entre mídia e eleitores apareça como um processo de convencimento - que pode ou não produzir resultados. A ênfase na reação dos indivíduos às informações disponíveis sobre a posição de outros indivíduos em seu ambiente (profissional, comunitário etc.) e, em alguns casos, a ênfase na tendência, pressuposta, a acompanhar o maior número, organizam algumas matrizes importantes das análises. Em uma delas, o destaque vai para os formadores de opinião nas comunidades e para a dinâmica de reforço das opiniōes já compartilhadas pelo grupo (Lazarsfeld, Berelson e Gaudet, [1944] 1969; Berelson, Lazarsfeld e Mcphee, [1954] 1986). Outra matriz, que também tem sido influente, ressalta a imposição das opiniōes da maioria às minorias, que seria um desdobramento do receio ao isolamento, constituindo a "espiral do silêncio" (Noelle-Neuman, [1993] 1995) ou as "pressōes do conformismo" (Sunstein, [2009] 2010, p. 52).

Nessas abordagens, a mídia é avaliada pelo reforço ou pela confrontação a disposiçōes prévias e majoritárias. Atuaria, assim, no sentido de confirmar ou suplantar o "preconceito violento, a apatia e a preferência pelas trivialidades" nos cidadãos (Lippmann, [1922] 1966, p. 229). Responderia a interesses preexistentes, confirmando-os, ou permitiria o contato dos indivíduos com aspectos da realidade - especialmente da política - cuja relevância eles não seriam capazes de perceber sem a indicação da própria mídia.

Muitos estudos sobre comportamento político, enfatizem ou não o papel dos meios de comunicação de massa, trabalham com uma percepção estilizada de como são produzidas as decisões políticas. Os indivíduos são vistos como dotados de um conjunto de valores ou preferências, com os quais ingressam na esfera pública. Pode ser um eleitor racional que busca o máximo de informaçóes (Ar- 
row, 1951) ou que, ao contrário, contenta-se com o mínimo de informação necessário para uma escolha esclarecida (Downs, 1957); pode ser um eleitor cujas escolhas são condicionadas integralmente pela socialização primária e que faz um uso seletivo da informação disponível, evitando a dissonância cognitiva (Campbell, Converse, Miller e Stokes, 1960); ou mesmo aquele que toma decisões de forma quase intuitiva, com base em baixa informação (Popkin, 1991). Em cada um desses casos, as preferências individuais, sejam elas consideradas esclarecidas ou fruto de preconceitos, aparecem como dados prévios, a partir dos quais os indivíduos se situam diante de um conjunto de informações, próprias da conjuntura e que pouco incidem sobre a formação das preferências. ${ }^{3}$

Então, os indivíduos são expostos a um universo de informações - sobre quais são as ofertas no mercado político, por um lado, e, por outro, sobre as questôes (issues) prementes e as alternativas a elas. Tendo sempre como horizonte os valores e preferências originários, que tendem a ser dados como fixos, o indivíduo analisa o mundo que o cerca, à luz das informaçôes disponíveis, e faz racionalmente sua opção. Todo o processo toma a forma de um silogismo, que pode ser enunciado de forma clara, ainda que não muito elegante, como se segue: uma vez que $x$ (preferência) e dado que $y$ (informação), $\operatorname{logo} z$ (decisão). Uma vez que eu priorizo a agenda ambiental e dado que as informaçôes indicam que o candidato Fulano possui os compromissos mais sólidos com a causa ecológica, logo eu voto nele. Esse tipo de raciocínio, ao qual chamamos de "modelo simples de produção da decisão política”, pode ser representado pela Figura 1.

O modelo permite conceder pesos variáveis à influência da mídia, de acordo com a força relativa de "preferências", de "informação" e do "cálculo

\section{Figura 1}

Modelo Simples de Produção da Decisão Política

\section{informaçóes}

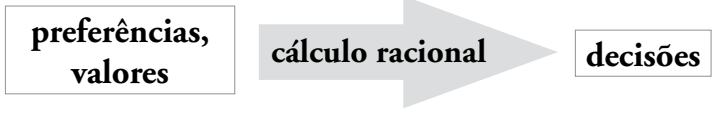

racional". Assim, num extremo, a narrativa lazarsfeldiana minimiza o centro do gráfico: as preferências (socialmente determinadas) já produzem diretamente escolhas eleitorais, cabendo à informação meramente reativá-las (Lazarsfeld, Berelson e Gaudet, [1944] 1969, pp. 74-75). No outro extremo, a narrativa schumpeteriana desinfla as preferências (já que os simples eleitores não são capazes de ter vontades efetivas em matéria de política) e elimina o cálculo racional, fazendo a escolha nascer diretamente da informação relevante em contexto de disputa eleitoral, que é o discurso demagógico (Schumpeter, [1942] 1984, p. 330). O mainstream da ciência política, porém, tende a ocupar posição mais central, com ênfase ora na capacidade dos eleitores de alcançar um cálculo racional eficiente diante das informações disponíveis (Downs, 1957; Sartori, [1987] 1994), ora no impacto manipulativo dos fluxos de comunicação (Sartori, [1997] 1998).

Não é nosso objetivo fazer, aqui, uma revisão exaustiva dos modelos de comportamento eleitoral. O ponto a observar é que os estudos de mídia tendem a trabalhar com uma variante do modelo simples, que chamamos de "modelo midiacêntrico de produção da decisão política" (Figura 2). Nele, a mídia é responsável tanto pela disseminação dos valores que conformam a "visão de mundo" do público, de longo prazo, quanto das informações que orientam suas escolhas no curto prazo. A ênfase pode ser dada a um ou outro aspecto, conforme o enfoque assumido.

O discurso da mídia entra, então, como variável explicativa da escolha política. Uma vez que tanto o eleitorado quanto os meios de comunicação são tomados como homogêneos, o modelo midiacên-

\section{Figura 2}

\section{Modelo Midiacêntrico de Produção da Decisão Política}

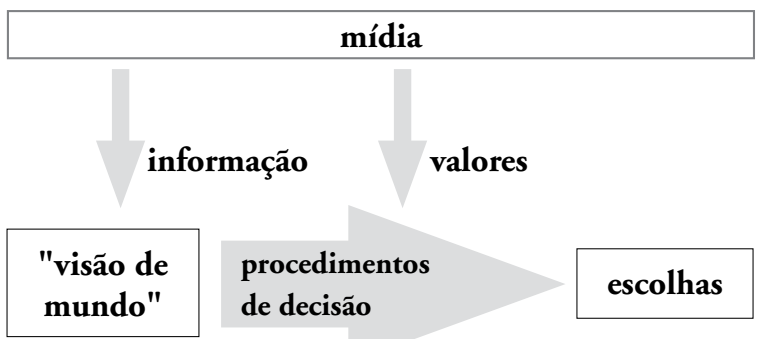


trico busca identificar para qual direção os meios apontam e, em seguida, verificar em que medida a transferência das disposiçõos para o público ocorreu eficazmente. A eleição de 1989, em que a preferência da mídia por Collor se traduziu em vitória eleitoral, desponta como um caso "normal". As eleiçōes presidenciais de 2006 e 2010 são as exceções que exigiriam explicações também excepcionais.

Há aqui um entendimento simplificador da relação que se estabelece entre aqueles que detêm "os instrumentos de produção de problemas e de opiniōes legítimas" (Bourdieu, 1979, p. 464), por sua vez resumidos à mídia, e aqueles que estão na posição de consumidores dos discursos considerados informativos e politicamente legítimos. É claro que a possibilidade de expressar politicamente uma opinião e, ainda, de fazê-la pesar na conformação do ambiente político, depende de instrumentos que não são distribuídos de forma equânime ou casual - a divisão do trabalho político tem como uma de suas facetas a divisão social entre produtores e consumidores do discurso político. Mas, numa sociedade diversificada - numa sociedade "ocidental", nos termos de Gramsci - os fluxos comunicativos e os espaços de decodificação das mensagens devem ser entendidos como arenas de conflito, nas quais há hegemonias, mas não monopólios.

A notória falência desses três pressupostos tem levado a diferentes respostas nos estudos de mídia e política. Uma delas é uma espécie de fuga para a frente, em que a aposta é estabelecer um quadro teórico e metodológico ainda mais rígido, que tem como um dos seus efeitos negar realidade ao que não está dentro dos limites do modelo analítico proposto. São, em alguns casos, modelos quantitativos simplificadores, que reduzem a complexidade dos processos político-midiáticos a algumas variáveis, a fim de estabelecer correlações matemáticas que "provariam" uma coisa ou outra, mas, com isso, afastam-se de sua compreensão efetiva. A explicação para o comportamento eleitoral pode, assim, estar em uma correlação entre a exposição estimada à mídia e o voto na oposição em 2006 (Mundim, 2010), em um modelo monocausal que vai da avaliação de um debate eleitoral à decisão do voto (Lourenço, 2010) ou mesmo na construção de uma equação que, devidamente alimentada, seria capaz de prognosticar a escolha do eleitorado (Eisenberg e Vale, 2009) - e estes são apenas alguns exemplos extremos. ${ }^{4}$

Propomos aqui que os estudos sobre comunicação e política caminhem na direção oposta. Não se trata de isolar um punhado de variáveis, de preferência quantificáveis, e tentar forçar a realidade para dentro de algum modelo que só reconheça a elas. É necessário, como discutimos na próxima seção, recuperar a complexidade na produção das escolhas políticas.

\section{Um mundo mais complexo}

Não é necessário tomar toda a complexidade do processo de formação das preferências ou do modo de atuação dos meios de comunicação nas mãos em cada análise, ou mesmo em cada hipótese que as pesquisas tornam explícita. Mas nos parece necessário que os pressupostos que orientam normativamente os passos que damos para tornar o mundo empírico explicável ganhem em complexidade. Caso contrário, podemos chegar a conclusōes que são retoricamente fortes, mas têm como ponto de partida ficções. E isso não é banal: com elas, podemos colaborar para que um mundo complexo seja visto de alguns prismas, e não de outros, fazendo parte das disputas ideológicas. ${ }^{5}$ É possível, no entanto, que colaboremos pouco para explicá-lo.

Uma das dificuldades parece ser considerar os efeitos da mídia de um modo que permita ultrapassar a alternativa entre comportamentos que correspondem ao discurso midiático e comportamentos que não correspondem. A ideia de que esse é o caminho para avaliar o impacto dos meios de comunicação - e, de modo mais geral, da atuação política da mídia em um dado contexto - esbarra em uma série de problemas, alguns deles indicados na seção anterior. Uma primeira ressalva é que não há um "momento" preciso em que a mídia entre no circuito. Não há um agente isento de exposição à mídia, com valores e comportamento não contaminados, que num momento posterior sofrerá essa influência.

A tendência a pensar esse processo como reação a informações disponíveis pode omitir o fato de que os meios de comunicação atuam, cumulativamente e a partir de diversos tipos de conteúdo, na própria definição daquilo que é interessante para os 
indivíduos. A atenção seletiva não é produto de um ambiente social anterior ou independente da presença da mídia. Os valores mobilizados para avaliar comportamentos e situações são produtos de uma sociedade midiatizada - ainda que um dos termos não contenha o outro. Isso não significa que as preferências e interesses resultem da mídia ou de discursos midiáticos específicos. E quando não resultam (de acordo com o recorte definido para avaliar a correspondência entre comportamento político e mídia), isso não significa que os meios de comunicação tenham deixado de participar do processo de produção das preferências e interesses.

Os meios de comunicação são centrais nas disputas pela produção das representações legítimas do mundo social. Isso não está sendo negado. Mas o sentido dessa afirmação é justamente que eles atuam em um ambiente em que há representações divergentes e conflitivas, e não apenas complementares. Há diferenças de foco e de enfoque internamente à "grande imprensa", internamente ao campo da mídia e, em especial, no ambiente social mais amplo, levando-se em conta que a mídia não detém o monopólio da produção das representações do mundo social. Em outras palavras, a construção dos discursos hegemônicos se dá em um ambiente de disputas. A criação de consensos só se coloca como um problema político porque há interesses divergentes $e$ que ganham expressões políticas divergentes. $\mathrm{O}$ poder de agenda da mídia, a concentração da propriedade de mídia e a prevalência de perspectivas e interesses específicos no discurso midiático não esgotam o âmbito em que as disputas simbólicas se travam.

Para que essa compreensão deixe de ser apenas um enunciado teórico ou retórico e passe a povoar, de fato, os pressupostos que orientam as pesquisas de mídia e política, é preciso, em primeiro lugar, romper com a visão de uma esfera pública unificada, entendendo que existem múltiplos circuitos e que esses circuitos não são estanques, mas diferenciados. ${ }^{6}$ Podemos definir o problema para esta discussão da seguinte forma:

1. A esfera pública não é homogênea: há valores diferentes, e divergentes, organizando a compreensão que públicos distintos têm do am- biente social mais amplo e do seu ambiente próximo. A compreensão da identidade de indivíduos e grupos sociais, assim como a compreensão da sua posição nas relações de poder, é constituída por esses valores e não está, portanto, contida na perspectiva social hegemônica. A sobreposição entre a posição dos meios de comunicação empresariais de grande público e as perspectivas socialmente hegemônicas, própria da organização do mercado de mídia numa economia capitalista, é relevante, mas não significa que as perspectivas hegemônicas se imponham aos públicos igualmente nem que os meios de comunicação sejam, interna e externamente, homogêneos.

2. A esfera pública é constituída de modo desigual: os públicos têm posições distintas e hierarquizadas. Os recursos, materiais e simbólicos, para a produção e difusão das representações sociais estão desigualmente distribuídos - e o acesso aos meios de comunicação é um fator importante nessa desigualdade. A distinção entre produtores e consumidores de informação é um de seus aspectos. A compreensão da identidade de indivíduos e grupos sociais, assim como a compreensão da sua posição nas relações de poder, depende da legitimidade que valores e interesses divergentes terão. E, fechando o ciclo (numa tautologia que é socialmente estabelecida), a legitimidade desses valores e interesses, por sua vez, depende da posição social dos públicos e dos recursos disponíveis a cada um.

3. A esfera pública é um espaço de disputas: a existência de públicos plurais e distintos não se acomoda em diferenças complementares. E as desigualdades não apagam os valores e interesses que têm menor visibilidade e legitimidade. As relaçóes de poder implicam hierarquias, mas não o apagamento das posições hierarquicamente inferiores. A produção dos discursos hegemônicos e a manutenção de posições vantajosas para alguns grupos sociais se dão por meio da produção de consensos provisórios e localizados que não esgotam os conflitos sociais. E não se trata, apenas, da oposição entre dominantes e dominados, mas das diferencia- 
ções entre os grupos que dispóem de recursos e posiçôes de poder em um dado contexto. Os meios de comunicação estão no centro dessas disputas porque são recursos (desigualmente distribuídos, como se disse acima) para a construção de consensos, a acomodação dos conflitos, a reprodução da dominação, mas também para a promoção de discursos antagônicos ou marginais.

A existência de diferentes públicos, com a potencial produção e adesão a representações sociais antagônicas, não quer dizer que estejam em pé de igualdade com os públicos e discursos dominantes. Além da diferença nas posiçóes de poder (acesso a recursos e espaços), a expressão de uns pode, facilmente, tomar vulto de interesses politicamente legítimos, enquanto a de outros pode não passar de uma projeção fraca da expressão política da diferença e da divergência.

O problema vai além da ausência de pluralidade, uma vez que nas democracias liberais contemporâneas ela é organizada em posições hierarquicamente desiguais. As desigualdades permanecem, portanto, como um desafio mesmo quando há públicos plurais. Um grau razoável de pluralidade interna e externa dos meios de comunicação, no sentido definido por Hallin e Mancini (2004), pode coexistir com uma "opinião pública" ao mesmo tempo autônoma - em relação ao Estado - e restritiva - em relação às múltiplas posições e perspectivas sociais que poderiam ganhar expressão como interesses políticos legítimos. Um dos pontos, aqui, é o fato de que grupos sociais com posições desigualmente vantajosas desenvolvem "estilos culturais desigualmente valorizados”. Sua expressão é marginalizada por pressóes cotidianas e institucionais (Fraser, 1992, p. 120), entre as quais se encontram as pressóes da mídia.

Além do fato de que os públicos têm recursos desiguais para fazer valer seus "estilos" e opiniōes, não são todas as opiniōes que serão transmutadas em decisões, ou mesmo alcançarão as esferas em que as decisões são tomadas. Em outras palavras, o fato de que existem públicos plurais, capazes de produzir representações alternativas e reconhecer, com base nelas, interesses divergentes, não implica que sejam igualmente capazes de transformar esses interesses em ações políticas com impacto sobre as regras que regem a vida social. Isso corresponde, de modo aproximado, à diferença entre "públicos fracos" e "públicos fortes" em Nancy Fraser (1992, p. 134), que destaca as barreiras entre sociedade civil, arenas deliberativas e arenas decisórias nas sociedades liberais contemporâneas. $\mathrm{Ou}$, em outras palavras, entre a opinião e a tomada de decisões.

A partir dessa distinção, pode-se retornar ao problema da produção das opiniōes para pensar na relação entre "públicos fracos" e "públicos fortes” ainda nesse âmbito. Há um continuum entre, de um lado, "públicos fortes" e a potencialidade de transformar opiniōes em decisões e, de outro, "públicos fracos" e a distância entre a expressão da opinião e seu impacto em arenas decisórias. Entre essas pontas, há matizes que são importantes para a nossa discussão.

As diferenças de recursos não estão presentes apenas na difusão da opinião, mas na sua produção, como foi dito anteriormente. $\mathrm{O}$ processo de produção das opiniōes, das preferências e dos interesses não é individual, mas remete às posições em uma coletividade, em redes desiguais que se estabelecem em contextos sociais concretos. Assim, "as preferências não são fixas e estáveis, mas se adaptam a uma ampla gama de fatores - incluindo o contexto em que a preferência é expressa, as regras legais existentes, escolhas passadas de consumo e a cultura em geral" (Sunstein, 1991, p. 5). E essas posições correspondem a graus diferentes de autonomia nesse processo. $\mathrm{O}$ fato de que os meios de comunicação de massa difundam representações sociais mais afins com os interesses de alguns grupos, e não de outros, tem impacto sobre o processo mais amplo de formação das preferências. Os valores associados aos grupos em vantagem nesse processo são apresentados como adequados e "socialmente" valorizados - isto é, valorizados por toda a sociedade, em um processo no qual a manifestação de julgamentos a partir de determinadas posições na sociedade se realiza, ganhando o status de julgamentos socialmente compartilhados.

A presença de visões antagônicas nos meios de comunicação, assim como a existência de espaços alternativos de produção e difusão de informa- 
ções - como veículos locais; jornais, rádios e TVs comunitárias; blogs e outros espaços e recursos permitidos pela internet; publicações de igrejas, instituiçôes educativas e ONGs -, que podem ser utilizados por grupos sociais marginalizados, não significa que exista capacidade igual de influência sobre a agenda mais abrangente ou a agenda de outros públicos. Por outro lado, esses veículos não constituem cadeias de informação paralelas ou estanques àquelas que a "grande imprensa" faz valer.

O campo da mídia tem centros e margens. Nele, há hierarquias entre os veículos informativos. Eles abrangem públicos menos ou mais amplos, correspondem em graus diversos aos critérios vigentes da qualidade jornalística e obtêm menor ou maior credibilidade diante de públicos que estão, também eles, em posições desiguais. Mas o fato de que podem corresponder a diferentes públicos, e influenciar públicos também específicos, faz com que seja preciso matizar a relação entre centro e periferia, ou ao menos observar que ela não é estanque. Blogs de internet ou formas de comunicação alternativas à empresarial (a comunicação governamental é o principal exemplo) não detêm, no campo da mídia, a mesma posição de um telejornal como o Jornal Nacional, da Rede Globo, líder de público no horário "nobre", ou de um jornal como a Folha de S. Paulo, mas podem ter impacto maior ou mais efetivo sobre determinados públicos.

As diferenças na abrangência e nos segmentos de público, e mesmo as diferenças nas abordagens entre veículos e formas de comunicação, não impedem que existam influências recíprocas, reafirmando o peso da grande imprensa na definição da agenda e na conformação dos enquadramentos predominantes. Do mesmo modo, a apresentação das informações de acordo com os cânones ético-profissionais do jornalismo permite que ganhem o status de informações objetivas, distinguindo-as das formas de comunicação reconhecidas como "autointeressadas" e rendendo credibilidade. A agenda de um grupo específico e sua promoção por veículos marginais no campo pode não surtir efeito sobre o ambiente político construído a partir das posições dominantes (no campo da produção intelectual, em sentido mais amplo, assim como na mídia e na política). Isso não significa que sua existência e sua relevância possam ser simplesmente descartadas. Seria preciso avaliar, em diferentes contextos, qual é o peso relativo dos públicos e das instâncias e dispositivos de produção e circulação de discursos aos quais efetivamente recorrem, na conformação das preferências de diferentes segmentos do público para, então, compreender seu impacto na conformação da esfera pública, nos debates que nela se travam e, de modo mais específico, no voto.

Para que essa ruptura com uma concepção unificada da esfera pública esteja presente nos estudos de mídia e política, é preciso, portanto, levar em conta que "a mídia" é formada por veículos de diversos tipos e que a concentração da propriedade não se traduz em um controle completo sobre o fluxo comunicativo. A mídia não é um conjunto homogêneo e centralizado. Se há representaçōes uniformes e convergentes da realidade social, há também ruídos, fissuras e representações antagônicas.

"A mídia" contém instâncias de produção de sentido que não se resumem à grande imprensa. Há pelo menos outros quatro subcampos que parecem atuar permanentemente, ainda que com pesos e alcance diferenciados, na construção dos consensos e na definição do ambiente político: a comunicação governamental, a mídia local, as novas mídias, propiciadas sobretudo pela internet, e as formas de ativação de redes tradicionais, como as igrejas e o sindicalismo. Instâncias que estabelecem relaçôes complexas com a grande mídia, com os discursos político-eleitorais e também entre si.

O rótulo "comunicação governamental" ou, para sermos mais exatos, "comunicação pública de Estado” (Weber, 2010) compreende uma multiplicidade de discursos, em primeiro lugar porque provém de diferentes fontes. São os três poderes constitucionais, nas instâncias federal, estadual e municipal, por sua vez também divididas em diversos braços com alguma autonomia na comunicação com o público - secretarias, ministérios, agências, fundações, autarquias, tribunais. Além disso, as formas de comunicação são múltiplas. A publicidade veiculada na mídia comercial é apenas a ponta mais visível de uma estrutura que inclui impressos 
dirigidos aos usuários dos serviços públicos, canais públicos de rádio e televisão, portais de internet, presença em redes sociais, agências de notícias, banners e outdoors etc. A cartografia desta comunicação apenas começou a ser realizada, no trabalho pioneiro de Maria Helena Weber (2010). ${ }^{7}$

O polo mais importante da comunicação de Estado é, evidentemente, a presidência da República, cuja política subordina - ainda que nem sempre com total êxito - os outros órgãos do Poder Executivo federal. No governo Lula, a presidência aprimorou de forma significativa seus mecanismos de comunicação, em especial aqueles que prescindem da intermediação dos grandes conglomerados de imprensa. Uma iniciativa particularmente importante foi a disponibilização de material pronto para utilização pelos veículos de comunicação do interior, na forma de texto, áudio e mesmo vídeo, nos portais do governo. Com isso, numa só tacada, a pauta e os enquadramentos do governo ganharam espaço e reduziu-se a influência dos órgãos centrais de mídia, que antes eram praticamente os únicos responsáveis por alimentar os pequenos veículos com notícias de fora do âmbito local, muitas vezes por meio da famosa gilete press (a leitura, nas emissoras de rádio, de recortes dos jornais).

A mídia local engloba, no Brasil, dezenas de milhares de pequenas publicações e emissoras, quase sempre desprezadas pela pesquisa acadêmica (por razões práticas mais do que compreensíveis). Embora cada veículo atinja um público reduzido, em conjunto sua penetração é muito significativa. Como são menos visíveis e também como em geral operam em ambiente de baixa competição, tendem a agir com mais liberdade nos períodos eleitorais, apoiando candidatos de forma mais ostensiva e respeitando menos do que na grande imprensa os rituais da objetividade jornalística. Os elos com essa grande imprensa - e, como visto, com a comunicação governamental - também são diversificados.

No que se refere à mídia local, o governo Lula também fez diferença. A verba publicitária foi pulverizada. Ela era atribuída a 499 veículos, de 182 municípios, no final do segundo mandato de Fernando Henrique Cardoso. Ao longo do governo Lula, passou a ser distribuída entre 8.094 veículos (jornais, revistas, rádio, TV, sites e blogs da inter- net), de quase 3 mil diferentes municípios (Rodrigues, 2010). Para os críticos, o governo estaria comprando o apoio de milhares de pequenos jornais e emissoras. Embora pequena para os padrōes da União, a verba publicitária representaria, para cada um deles, um aporte financeiro considerável - que eles não se arriscariam a perder com uma cobertura adversa ao anunciante. Ao contrário das grandes empresas, não teriam peso e influência para garantir simultaneamente a manutenção da publicidade governamental e a independência jornalística.

Já para os defensores da medida, seu principal efeito é o oposto. A sustentação financeira aos pequenos veículos garantiria o pluralismo na mídia brasileira, não apenas impedindo seu fechamento ou absorção por empresas maiores como também propiciando recursos para sua maior profissionalização. Seja como for, o novo padrão de distribuição da verba publicitária do governo federal gerou uma mídia local mais forte - se não diante do governo, ao menos diante dos veículos de comunicação centrais.

Uma proporção elevada dos veículos que recebem verba do governo federal está baseada na internet, ${ }^{8}$ o que por si só é um dado relevante. $\mathrm{O}$ potencial das novas tecnologias, como instrumentos de participação política e de democratização da comunicação, ainda é tema para muitas polêmicas. ${ }^{9}$ Não há dúvida, porém, de que há a presença de novas redes comunicativas, que fazem circular uma pluralidade de discursos alternativos sobre as disputas políticas. Esses discursos muitas vezes ecoam e retrabalham aqueles emanados dos centros da vida política ou do noticiário da grande imprensa, mas há aí espaço para mudanças de ênfase ou de abordagem. Três casos, todos extraídos da campanha presidencial de 2010, permitem discutir a influência da internet nas campanhas eleitorais.

Primeiro caso: insatisfeitos com o tom, que julgavam excessivamente cordato, da propaganda de José Serra na TV, seus aliados do partido Democratas veicularam na internet um conjunto de vídeos em tom agressivo contra a candidata adversária, Dilma Rousseff. Além da divulgação na própria internet, por meio dos apoiadores do partido que veiculavam os links em suas listas e páginas em redes sociais, os vídeos obtiveram repercussão na mídia convencional, o que seguramente ampliou o núme- 
ro de internautas que os procuraram. O episódio demonstrou que há, por parte dos comandos de campanha, uma capacidade relativamente reduzida de controle sobre os discursos que circulam na arena eleitoral. As estratégias de campanha não se resumem àquelas oficialmente adotadas e atores com posiçôes pouco destacadas ou mesmo marginais na campanha podem, por meio da internet, amplificar seus discursos para além da própria rede.

Segundo caso: a partir do final da campanha para o primeiro turno, o PSDB apostou na exploração do tema do aborto, acusando o PT de ser favorável à sua legalização. A revelação de que a mulher do candidato Serra já teria praticado um aborto voluntário, postada na página pessoal de uma ex-aluna sua em uma rede social, obrigou que o partido recuasse, abandonando parcialmente esta estratégia. Mais uma vez, há um passo inicial (postagem no Facebook), amplificado por iniciativa de outros internautas e, sobretudo, pela repercussão na mídia convencional. $\mathrm{O}$ que torna notável o episódio é que, aparentemente, a divulgação da informação na página pessoal teve o caráter de um desabafo, sem intenção de chegar aos jornais. O episódio evidenciou que o controle sobre a agenda e a imagem pública dos candidatos se tornou ainda mais disputado e vulnerável a fluxos divergentes de informação. No caso, a opção pelas vantagens do agendamento de uma temática levou a uma exposição da mesma temática sob prismas desvantajosos, sem necessariamente alterar o framing de base, a condenação ao aborto.

Terceiro caso: o candidato José Serra alegou, em meio à campanha do segundo turno, ter sido agredido por militantes petistas; a campanha de Rousseff afirmou que ele foi atingido apenas por uma bolinha de papel. A polêmica tomou conta da propaganda eleitoral, do noticiário e também da internet. As múltiplas versões alternativas que circularam na rede reduziram o peso do laudo pró-Serra apresentado pelo "perito" Ricardo Molina em pleno Jornal Nacional, da Rede Globo, dando aos apoiadores de Rousseff argumentos para se colocarem no debate. Este é, talvez, um dos efeitos mais importantes dos novos meios. Se uma das funçōes da mídia é fornecer um repertório de argumentos que permite a quem defende aquela po- sição se tornar mais ativo no debate com pessoas próximas, como diz Noelle-Neuman ([1993] 1995, p. 226), a internet pode eventualmente ser um recurso para promover as vozes minoritárias no debate, contrapondo-se à grande imprensa.

Em todos os casos, há uma relação complexa entre os conteúdos que circulam de forma pulverizada pelos novos meios - que não são indistintos entre si, uma vez que há uma hierarquia que começa nos grandes portais e nos blogs de jornalistas famosos e termina nas páginas de usuários anônimos -, os discursos partidários oficiais e o noticiário da grande mídia. O primeiro impacto se dá na construção do ambiente informacional dos próprios jornalistas, o que já denuncia a continuidade da posição central da mídia convencional. ${ }^{10}$ Mas a internet estabelece novos circuitos de difusão de informação, que têm sido utilizados de forma menos ou mais criativa, menos ou mais eficaz, por diferentes agentes políticos, alguns deles à margem de outros processos e atalhos para tomar parte da discussão pública. Sua influência é crescente, sobretudo (mas não só) nos segmentos jovens, urbanos e escolarizados, e, embora não tenhamos nos aproximado um único milímetro das fantasias da informação livre e descentralizada (Lévy, [1994] 1998; Ludlow, 2001; Saco, 2002), trata-se de uma instância que já não pode ser ignorada.

A internet tornou-se também uma ferramenta que agiliza a ativação de redes tradicionais de comunicação e influência política. Tais redes, no entanto, existem a despeito dela e retiram sua força de outras formas de vínculo. $\mathrm{O}$ caso das igrejas permite observar como é difícil determinar o que é "mídia" na rede de discursos com impacto público. Católicos e protestantes detêm concessões de rádio e televisão, apresentando programação religiosa, orientada por valores religiosos e/ou marcada por sua posição ideológica. Também possuem sua mídia interna (de publicações voltadas ao público eclesiástico a boletins paroquiais). Por outro lado, as declarações de seus principais líderes ecoam na mídia comercial. Mas grande parte da sua influência provém do contato direto entre sacerdotes e fiéis ou dos sermóes pronunciados durante os cultos que, tecnicamente, são formas de comunicação não mediadas. O conteúdo desses discursos, porém, é 
alimentado pelas diferentes comunicações mediadas que informam a esses sacerdotes as posiçōes e prioridades das cúpulas de suas igrejas.

Na eleição presidencial de 2010, a importância das igrejas se fez sentir. A campanha contra o PT e a candidata Rousseff, por seu pretenso apoio ao direito ao aborto e ao casamento gay, começou nelas, antes de chegar ao noticiário e ao discurso dos candidatos. A agenda das eleiçôes foi, em vários momentos, delineando-se como reação a posições e discursos que não ganharam forma, inicialmente, na grande imprensa (Mantovani, 2012). Muitas caracterizaçōes, julgamentos e acusaçōes foram divulgados dentro das igrejas, dentro de ônibus urbanos ou por meio de panfletos distribuídos nas ruas. Parte delas ecoou, a partir desses espaços ou simultaneamente à sua circulação nesses espaços, em e-mails, blogs, sites de notícia, veículos convencionais e também na propaganda dos candidatos. Além disso, despertaram diferentes reações internamente às alianças e à organização das campanhas, explicitando conflitos e estratégias nem sempre unificadas, como foi mencionado acima.

Mas o ponto principal para esta discussão é que os fluxos foram variados. Houve, em diferentes momentos, esforços por parte dos candidatos para amplificar esses discursos ou para reduzi-los. Temas e discursos impuseram-se a partir de espaços relativamente marginais ao complexo jornalismo-campanhas-Estado, ou, em outras palavras, às formas reguladas do contato entre o mundo jornalístico e o da política. A "grande imprensa" respondeu a uma agenda imprevista, assim como atuou no sentido de dar forma a ela, definindo suas margens, promovendo alguns enquadramentos e vozes em detrimento de outros. Trabalhou, também, no sentido de estabelecer consensos, aproximando-se em graus variados da agenda conservadora dos grupos religiosos.

É difícil mensurar o efeito da tematização do aborto e das posiçōes assumidas pelas igrejas no resultado das eleiçôes - aliás, toda a argumentação desenvolvida neste artigo busca demonstrar a complexidade da decisão eleitoral, opondo-se à ideia de que é possível realizar um cálculo mecânico de efeitos -, mas certamente foram beneficiados os candidatos mais conservadores, isto é, José
Serra e Marina Silva. ${ }^{11}$ E há dificuldades, também, para a análise de como se deu a interação entre os diferentes agentes e discursos na concorrência pela definição da agenda e do ambiente político em que as disputas ganharam sentido. Eliminar ou menosprezar variáveis pode tornar essa realidade mais domesticada dentro dos limites de cada análise, mas não serve para explicar, por exemplo, quais foram os pesos relativos dos diferentes atores diante de públicos determinados - e qual foi, numa visada mais ampla, o significado da opção por um ou outro candidato em diferentes localidades e segmentos do eleitorado.

\section{Conclusão}

$\mathrm{O}$ ambiente em que as preferências políticas são produzidas é multifacetado. Grande imprensa, discurso político-partidário, comunicação dos agentes do Estado, mídia local, novas tecnologias, redes discursivas tradicionais: todas essas instâncias estabelecem relaçôes complexas entre si. Não é possível determinar a priori o peso de cada uma, já que suas posiçōes mudam de acordo com as conjunturas e, além disso, diferentes segmentos do público são diferentemente suscetíveis a cada uma delas.

Mais que isso, é um ambiente constituído por disputas e antagonismos. Os discursos tomam forma a partir de lugares, instituições e agentes hierarquicamente posicionados no acesso a recursos para produção e difusão das informações. Essas hierarquias não dizem respeito apenas ao acesso aos recursos materiais, mas também ao fato de que a legitimidade social das informaçóes não é sempre idêntica - os públicos reconhecem diferentemente a competência discursiva e a "isençãa" dos agentes na produção das informações. Mas o fato de que essas hierarquias existam não corresponde a um apagamento dos agentes que estão em posições marginais ou da possibilidade de que suas experiências tomem a forma de interesses que colocam em questão os discursos hegemônicos.

O acúmulo das reflexões teóricas e dos estudos sobre a mídia e o comportamento eleitoral permite avançar para uma conclusão pouco confortável: o peso dos diferentes agentes no campo da produção 
ideológica e dos discursos que fazem circular não é plenamente regulado ou previsível, ainda que se dê destaque - como procuramos dar - às desigualdades no acesso a recursos. $\mathrm{O}$ ponto aqui é que as hierarquias entre os produtores de discurso não são estáveis e não podem ser assim compreendidas quando se tem como preocupação o efeito produzido pelos diferentes veículos e processos de comunicação na formação das preferências dos indivíduos. E isso se dá por pelo menos três razões: o público é diverso e, portanto, seu acesso a informações e sua possibilidade de compartilhar os critérios que atribuem relevância às informações difere; a mídia é diversa (externa e mesmo internamente) e os diferentes segmentos de público estabelecem relaçôes também diversas com os veículos de mídia, podendo contornar, parcial ou momentaneamente, as hierarquias "objetivas" entre os veículos; há fluxo comunicativo entre os diferentes lugares em que a produção e a recepção se dão, e esse fluxo não é algo que atenda a um modelo simples de difusão centro-periferia.

No contexto brasileiro, essa complexidade vem se ampliando. Da eleição de Collor em 1989 até hoje, mais de vinte anos se passaram. Muita coisa mudou. $\mathrm{O}$ cenário político-partidário se rearranjou, com a pulverização inicial sendo substituída pela polarização entre PSDB e PT e a paulatina transformação do PT num partido centrista. O mercado de mídia também mudou, com a redução da hegemonia da Rede Globo. As camadas com maior poder aquisitivo hoje têm acesso à TV por assinatura e uma parcela ainda maior da população faz uso da internet. O eleitorado mostra-se mais crítico, ou mesmo mais cético, em face tanto das potencialidades do processo eleitoral que deixou de ser visto como o momento da "grande mudança" - como dos discursos dos candidatos. Com tantas e tão profundas mudanças, seria espantoso se a influência da mídia sobre as eleições permanecesse inalterada.

A mídia de grande público mantém-se em posição central nas disputas pela construção simbólica do mundo social e pela definição das preferências. E essa centralidade corresponde a uma potência: a de fazer ver e atribuir relevância a aspectos do mundo social que se tornam visíveis atrelados a julga- mentos e posições. Mas trata-se de uma potência, que se realiza de forma que precisa ser claramente definida em cada situação. Seus efeitos tomam forma ao longo do tempo, o que nos afasta da ideia de que é possível avaliar seu peso na produção das preferências como efeito mecânico direto. A construção de consensos e a definição dos limites das disputas podem estar em curso, com importante participação das empresas de comunicação e da "grande imprensa", mesmo quando o candidato da mídia não é o mais votado. E seus efeitos se definem na interação com outros agentes, atendendo a graus variáveis de conflito.

Como se trata de uma interação conflituosa, não é possível imaginar que as mensagens simplesmente se somam ou se complementam. Elas competem ativamente, mobilizando seus recursos diferenciados, e são apropriadas, também de forma diferenciada, pelos diferentes grupos sociais em disputa. À luz disto, fica claro que o campo das pesquisas sobre as relaçõos entre a mídia e a política, e, nele, especialmente as pesquisas sobre o impacto da mídia na produção das preferências, avança com análises historicamente situadas, e perde em complexidade com modelos abstratos de aplicação pretensamente universal. Em suma, que é hora de retomar o velho caráter compreensivo que singulariza a ciência social.

\section{Notas}

1 Para uma descrição da metodologia do Doxa, principal fonte dos estudos de valência no Brasil, ver Aldé, Mendes e Figueiredo (2007).

2 O conceito de "cenário de representação da política" (CR-P), utilizado nos anos de 1990 a partir da elaboração de Venício A. de Lima (1994, 1995, 1996), tinha o mérito de reconhecer que as escolhas eleitorais começam a ser construídas muito antes do início das campanhas, já que pesam não apenas informações factuais, mas também valores que vão orientar a interpretação do mundo pelos votantes. No entanto, o CR-P fixava arbitrariamente um período de doze meses antes da eleição como relevante para o entendimento das opções eleitorais, concedia à mídia (e, dentro dela, aos programas de maior audiência) um poder absoluto na conformação das representações 
do mundo social e baseava-se num referencial teórico confuso, que combinava, sem maiores problemas, tradições antagônicas como "imaginário" (na versão de Baczko), "cultura política" (Almond e Verba) e "hegemonia" (Gramsci).

3 Para revisôes dos modelos explicativos do voto, ver Mayer (1997), Figueiredo (1991) e Lau e Redlawski (2004).

4 Para uma crítica mais detida, ver Biroli e Miguel (2011).

5 É comum, por exemplo, que órgãos da imprensa, por vezes com indisfarçada orientação ideológica ou mesmo partidária, aproveitem resultados de pesquisas acadêmicas que, descontextualizados, servem para exaltar a "imparcialidade" de seu noticiário em comparação com os concorrentes. É o que ocorre a cada eleição, por exemplo, com os dados do Doxa.

6 Essa discussão parte da crítica de Nancy Fraser (1992) ao conceito de esfera pública em Habermas, sem permanecer fiel ao foco e aos argumentos da autora. É fundamental o entendimento de que a ausência de impedimentos formais à participação e à expressão não é capaz de suspender as desigualdades sociais efetivas. A suspensão favorece os grupos dominantes, entre outras coisas porque impede a tematização das desigualdades e apresenta seus valores como universais. Cf., em especial, o item 3, "Open access, participatory parity and social equality"; para discussões afins, cf. também Young (1990), especialmente o capítulo 4, e Miguel e Biroli (2010).

7 Para um mapeamento detalhado do funcionamento da mídia da Câmara dos Deputados, conferir Brum (2010).

8 Os dados disponibilizados pelo governo ainda incluem portais, sites e blogs na categoria "outros", ao lado de propaganda em cinema, outdoors ou banners. "Outros" responde por 31\% dos veículos de comunicação que receberam publicidade do governo federal em 2010 - eram 2,2\% ao final do governo Fernando Henrique Cardoso.

9 Para uma ampla resenha, ver Gomes (2008).

10 Embora os líderes políticos gostem de ostentar os números inflados de seus "seguidores" no Twitter, o miniblog é usado por eles sobretudo como uma ferramenta que facilita o contato com os profissionais de imprensa.

11 O Datafolha "mediu" o impacto, concluindo que $3 \%$ dos eleitores deixaram de voltar em Rousseff por conta do escândalo de corrupção na Casa Civil e outros $1 \%$ por causa da campanha contrária das igrejas. Por outro lado, os escândalos deram a ela $2 \%$ do eleitorado, que passaram a votar nela por causa das denúncias de corrupção. $\mathrm{O}$ resultado líquido dos escândalos e do antiabortismo seria, assim, idêntico. O resultado bizarro reflete o método tacanho - os entrevistados declaravam a mudança de voto e informavam o motivo (Canzian, 2010).

\section{BIBLIOGRAFIA}

ALDÉ, Alessandra. (2004), "As eleiçōes presidenciais de 2002 nos jornais", in Antonio Albino Canelas Rubim (org.), Eleiçôes presidenciais em 2002 no Brasil: ensaios sobre mídia, cultura e política, São Paulo, Hacker.

ALDÉ, Alessandra; MENDES, Gabriel \& FIGUEIREDO, Marcus. (2007), “Tomando partido: imprensa e eleições presidenciais em 2006”. Politica \& Sociedade, 10: 153-172.

ARROW, Kenneth J. (1951). Social choice and individual values. Nova York, John Wiley and Sons.

BERELSON, Bernard R.; LAZARSFELD, Paul F. \& MCPHEE, William N. ([1954] 1986), Voting: a study of opinion formation in a presidential campaign. Chicago, Chicago University Press.

BIROLI, Flávia. (2005), "Política da ausência: diagnósticos da incompetência da (e para a) democracia no debate político no Brasil, anos 1955-1960", in Izabel Marson e Márcia Naxara (orgs.), Sobre a humilhação: sentimentos, gestos, palavras, Uberlândia, Edufu.

BIROLI, Flávia \& MANTOVANI, Denise. (2010), "Disputas, ajustes e acomodações na produção da agenda eleitoral: a cobertura jornalística ao Programa Bolsa Família e as eleições de 2006”. Opinião Pública, 16 (1): 90-116.

BIROLI, Flávia \& MIGUEL, Luis Felipe. (2011), "Razão e sentimento: a comunicação política e a decisão do voto". Paper apresentado ao XX Encontro da Associação Nacional do Programas de Pós-Graduação em Comunicação (Compós). Porto Alegre, 14 a 17 de junho. (2012), "Orgulho e preconceito: a objetividade como mediadora entre o jornalismo 
e seu público". Opiniāo Pública, 18 (1): 22-43. BOURDIEU, Pierre. (1979), La distinction: critique sociale du jugement. Paris, Minuit. (1997), Méditations pascaliennes. Paris, Seuil.

BRUM, Cristiane. (2010), Politica, institucional ou pública? Uma reflexão sobre a mídia legislativa da Câmara dos Deputados. Tese de doutorado, Rio de Janeiro/ Brasília, UERJ/Cefor-Câmara dos Deputados.

CAMPBELL, Angus; CONVERSE, Philip E.; MILLER, Warren E. \& STOKES, Donald E. (1960), The American voter. Chicago, Chicago University Press.

CANZIAN, Fernando. (2010), "Caso Erenice mudou mais votos do que temas religiosos". Folha de S. Paulo, 11 de outubro, p. A-4.

DOWNS, Anthony. (1957), An economic theory of democracy. Nova York, Harper \& Brothers.

EISENBERG, José \& VALE, Teresa Cristina de S. C. (2009), "Simulação eleitoral: uma nova metodologia para a ciência política". Opiniāo Pública, 15 (1): 190-223.

FIGUEIREDO, Marcus. (1991), A decisão do voto. São Paulo, Sumaré.

FOUCAULT, Michel. ([1979] 1995), Microfisica do poder. Rio de Janeiro, Graal.

FRASER, Nancy. (1992), "Rethinking the public sphere: a contribution to the critique of actually existing democracy", in Craig Calhoun (ed.), Habermas and the public sphere, Cambridge, The MIT Press.

GOMES, Wilson. (2008), "Internet e participação política”, in Wilson Gomes e Rousiley C. M. Maia, Comunicação e democracia: problemas e perspectivas, São Paulo, Paulus.

HALLIN, Daniel C. \& MANCINI, Paolo. (2004), Comparing media systems: three models of media and politics. Cambridge, Cambridge University Press.

LATTMAN-WELTMAN, Fernando; CARNEIRO, José Alan Dias \& RAMOS, Plínio de Abreu (1994), A imprensa faz e desfaz um presidente: o papel da imprensa na ascensão e queda do fenômeno Collor. Rio de Janeiro, Nova Fronteira.

LAU, Richard L. \& REDLAWSK, David P. (2004),
How voters decide: information processing during election campaigns. Cambridge, Cambridge University Press.

LAZARSFELD, Paul F.; BERELSON, Bernard \& GAUDET, Hazel. ([1944], 1969), The people's choice: how the voter makes up his mind in a presidential campaign. Nova York, Columbia University Press.

LÉVY, Pierre. ([1994] 1998). A inteligência coletiva: por uma antropologia do ciberespaço. São Paulo, Loyola.

LIMA, Venício A. de. (1994), "Televisão e poder: a hipótese do cenário de representação da política”. Comunicação \& Política, nova série, 1: $5-22$.

(1995), "CR-P: novos aspectos teóricos e implicaçôes para a análise política”. Comunicação \& Política, nova série, 3: 95-106.

(1996), "Os mídia e o cenário de representação da política”. Lua Nova, 38: 239271.

LIPPMANN, Walter. ([1922] 1966). Public opinion. Nova York/Londres, Free Press/Collier-MacMillan.

LOURENÇO, Luiz Cláudio. (2010), "Na tela e nas urnas: novas evidências da influência dos debates e da propaganda eleitoral na decisão do voto presidencial em 1989”. Paper apresentado no $34^{\circ}$ Encontro Anual da Associação Nacional de Pós-Graduação em Pesquisa em Ciências Sociais (Anpocs), Caxambu, de 25 a 29 de outubro.

LUDLOW, Peter (ed.). (2001), Crypto anarchy, cyberstates, and pirate utopias. Cambridge (MA), The MIT Press.

MANTOVANI, Denise. (2012), "Eleições: como os enquadramentos e as vozes organizaram os limites da controvérsia do aborto em 2010". Paper apresentado ao GT Comunicação Política e Opinião Pública do $8^{\circ}$ Encontro da Associação Brasileira de Ciência Política, Gramado, 1 a 4 de agosto.

MARQUES, Rosa Maria; LEITE, Marcel Guedes, MENDES, Áquilas \& FERREIRA, Mariana Ribeiro Jansen. (2009), "Discutindo o papel do programa Bolsa Família na decisão das eleições presidenciais brasileiras de 2006”. Revista 
de Economia Politítica, 29 (1): 114-132.

MAYER, Nonna (dir.). (1997), Les modèles explicatifs du vote. Paris, L'Harmattan.

MIGUEL, Luis Felipe. (1999), "Mídia e manipulação política no Brasil: a Rede Globo e as eleiçôes presidenciais de 1989 a 1998". Comunicação \& Política, nova série, VI (2-3): 119-138.

MIGUEL, Luis Felipe. (2003), "A eleição visível: a Rede Globo descobre a política em 2002". Dados, 46 (2): 289-310. . (2004), "Discursos cruzados: telenoticiários, HPEG e a construção da agenda eleitoral". Sociologias, 11: 238-258.

MIGUEL, Luis Felipe \& BIROLI, Flávia. (2010), "Visibilidade na mídia e campo político no Brasil". Dados, 53 (3): 695-735.

MUNDIM, Pedro. (2010), "O papel da cobertura da imprensa no realinhamento eleitoral de 2006: notas sobre a variável 'esquecida'. Paper apresentado no XIX Encontro da Associação Nacional dos Programas de Pós-Graduação em Comunicação (Compós), Rio de Janeiro, de 8 a 11 de junho.

NOELLE-NEUMAN, Elisabeth. ([1993] 1995), La espiral del silencio: opinión publica, nuestra piel social. Barcelona, Paidós.

POPKIN, Samuel L. (1991), The reasoning voter: communication and persuasion in presidential campaigns. Chicago, The University og Chicago Press.

PORTO, Mauro. (1995), “Telenovelas e política: o CR-P da eleição presidencial de 1994". Comunicação \& Política, nova série, 1 (1): 89-116.

RODRIGUES, Fernando. (2010), "Lula coloca publicidade estatal em 8.094 veículos". Folha de S. Paulo, 28 de dezembro, p. A-4.

RUBIM, Antonio Albino Canelas. (2004), "Visibilidades e estratégias nas eleições presidenciais de 2002: política, mídia e cultura”, in (org.), Eleiçōes presidenciais em 2002 no Brasil: ensaios sobre midia, cultura e politica, São Paulo, Hacker.

RUBIM, Antonio A. C. \& AZEVEDO, Fernando. (1998), "Mídia e política no Brasil". Lua Nova, 43: 189-216.

SACO, Diana. (2002), Cybering democracy: public space and the internet. Minneapolis, University of Minnesota Press.

SARTORI, Giovanni. ([1987] 1994), A teoria da democracia revisitada. São Paulo, Ática, 2 vols. ([1997] 1998), Homo videns: la sociedad teledirigida. Buenos Aires, Taurus.

SCHUMPETER, Joseph. ([1942] 1984), Capitalismo, socialismo e democracia. Rio de Janeiro, Jorge Zahar.

SUNSTEIN, Cass R. (1991), "Preferences and politics". Philosophy and Public Affairs, 20 (1): 3-34.

([2009] 2010), Rumores: como se difunden las falsedades, por qué nos las creemos y qué se puede hacer contra ellas. Buenos Aires, Debate.

THOMPSON, John B. ([1990] 2002). Ideologia e cultura moderna: teoria social crítica na era dos meios de comunicação de massa. Petrópolis, Vozes.

WEBER, Maria Helena. (2010), "Sobre a produção de comunicação pública de Estado e a disputa de opinião e visibilidade política". Paper apresentado no $34^{\circ}$ Encontro Anual da Associação Nacional de Pós-Graduação em Pesquisa em Ciências Sociais (Anpocs), Caxambu, de 25 a 29 de outubro.

YOUNG, Iris Marion. (1990), Justice and the politics of difference. Princeton, Princeton University Press.

ZUCCO, Celso. (2008), "The president's 'new constituency': Lula and the pragmatic vote in Brazil's 2006 presidential elections". Journal of Latin American Studies, 40 (1): 29-49. 


\section{MEIOS DE COMUNICAÇÃO, VOTO E CONFLITO POLÍTICO NO BRASIL}

\section{Flávia Biroli e Luis Felipe Miguel}

Palavras-chave: Mídia; Preferências políticas; Voto; Democracia.

$\mathrm{O}$ artigo discute a relação entre a comunicação e a definiçãao das preferências políticas ou, dito de outro modo, a atuação da mídia na conformação da opinião pública. Apresenta, inicialmente, uma crítica aos estudos sobre mídia e eleições no Brasil, voltada para três problemas: a pressuposição de que os processos de comunicação se dão de forma unilateral e regulada, projetando a existência de um eleitorado mais homogêneo do que de fato é; de que "a mídia” é um bloco monolítico, redutível aos principais conglomerados de comunicação; e a compreensão das relações entre mídia e eleitorado a partir desses dois pressupostos simplificadores. Procuramos indicar caminhos para visões mais sofisticadas dessa relação, levando em conta a diversidade do tecido social e a complexidade dos processos comunicativos, em que a comunicação governamental ganha destaque, as dissonâncias no interior dos veículos merecem atenção e circuitos alternativos de produção de sentido não são ignorados.

\section{MEDIA, VOTING AND POLITICAL CONFLICT IN BRAZIL}

\section{Flavia Biroli and Luis Felipe Miguel}

Keywords: Media; Political preferences; Vote; Political conflict; Democracy.

The article discusses the connections between media and definition of political preferences or, in other words, the action of the media in influencing public opinion. It starts with a critical analysis over the studies on media and elections in Brazil, focusing three topics: the assumption that the processes of communication occur in a unilateral and regulated form, projecting an electorate more homogeneous than it really is; the conception of the media as a monolithic block susceptible of being reduced to the major communication conglomerates; and the understanding of the relations between media and electorate on the basis of those two simplifying presuppositions. After such analysis, the authors propose some analytical paths for reaching a more complex and refined vision of the relationship between media, political preferences and vote. In this sense, they point to the need of taking into account the diversity of the social environment and the complexity of the communicative processes, in which governmental communication must be considered, as well as the dissonances within media vehicles, and the alternative circuits producing political meanings.

\section{MÉDIAS, VOTE ET CONFLIT POLITIQUE AU BRÉSIL}

\author{
Flávia Biroli et Luís Felipe Miguel
}

Mots-clés: Médias; Préférences politiques; Vote; Conflit politique; Démocratie.

L'article analyse la relation entre la communication et la définition des préférences politiques ou, en d'autres termes, le rôle des médias dans la formation de l'opinion publique. Il commence par une critique des études sur les médias et les élections au Brésil, en mettant l'accent sur trois problèmes : la présupposition que les processus de communication se produisent de façon unilatérale et régulée, en supposant l'existence d'un électorat plus homogène qu'il ne l'est vraiment; le fait que les " médias " sont un bloc monolithique, réductible aux principaux conglomérats de communication; et la compréhension des rapports entre les médias et les électeurs à partir de ces deux hypothèses simplificatrices. Nous cherchons ainsi à indiquer des voies pour une compréhension plus sophistiquée de cette relation, en tenant compte de la diversité du tissu social et de la complexité des processus de communication, dans lesquels la communication du gouvernement est mise en valeur. Les dissonances à l'intérieur des moyens de communication méritent une attention particulière, mais sans ignorer les circuits alternatifs de production. 